\title{
PENGARUH PEMBERIAN JUS LIDAH BUAYA (ALOE VERA) TERHADAP KADAR KOLESTEROL LOW DENSITY LIPOPROTEIN (LDL) DAN HIGH DENSITY LIPOPROTEIN (HDL)
}

\author{
Yulika Sianipar, Muflihah Isnawati ${ }^{*}$ \\ Program Studi Ilmu Gizi Fakultas Kedokteran Universitas Diponegoro \\ Jl.Dr.Sutomo No.14, Semarang, Telp (024) 8453708, Email : gizifk@ undip.ac.id
}

\begin{abstract}
Backgroud: Dislipidemia is a main major of cardiovascular diseases. Aloe vera contains several component considered to lower cholesterol levels in blood. The pupose of this research was to determine the effect of Aloe vera juice on HDL cholesterol and LDL cholesterol serum in dyslipidemia women.

Method : This study is was true experiment using control group with pre and post test design. The subject were women in Dinas Koperasi and UKM Provinsi Jawa Tengah with Balai Latihan Koperasi and UKM Provinsi Jawa Tengah who taken by consecutive sampling, subject consist of 43 people were divided in to three group, they are one control group, wasn't given treatment and two treatment group, given diet containing $100 \mathrm{mg} /$ day and 200 mg/day Aloe vera juice for 14 days. LDL cholesterol and HDL cholesterol level LDL cholesterol and HDL cholesterol serum level was determined using enzymatic method. Data were analysed using paired t-test and one way anova. The degree of significant was $5 \%$.

Result : The administration of the second treatment group, Aloe vera juice is significantly $(p<0,05)$ decreasing LDL cholesterol and increasing HDL cholesterol. LDL cholesterol serum may decreasing 20,36\% and increasing HDL cholesterol 18,87\% on the second treatment group after given Aloe vera juice for 14 days. The administration of the first treatment group not only significantly $(p>0,05)$ show decreasing $L D L$ and also decreasing HDL cholesterol but not significant decreased ( $p>0,05)$.
\end{abstract}

Conclusion: The administration $200 \mathrm{mg} /$ days of aloe vera juice is significantly (p<0,05) decreasing 20,36\% LDL cholesterol and increasing HDL cholesterol 18,87\% for 14 days.

Keyword: aloe vera juice; HDL; LDL; hiperlipidemia

\begin{abstract}
ABSTRAK
Latar Belakang: Dislipidemia merupakan salah satu faktor risiko terjadinya penyakit jantung koroner. Lidah buaya (Aloe vera) mengandung beberapa bahan aktif dapat menurunkan kolesterol dalam darah. Penelitian ini bertujuan untuk mengetahui pengaruh pemberian jus lidah buaya dengan dosis bertingkat terhadap kolesterol LDL dan kolesterol HDL pada wanita dislipidemia.

Metode : Penelitian ini merupakan true experiment dengan pre test - post test with control group design. Subjek penelitian adalah karyawati di Dinas Koperasi dan UKM Provinsi Jawa Tengah serta Balai Latihan Koperasi dan UKM Provinsi Jawa Tengah yang diambil secara consecutive sampling, besar sampel adalah 43 orang yang dibagi secara acak dalam tiga kelompok. Kelompok kontrol tidak diberi lidah buaya, kelompok perlakuan 1 dan kelompok perlakuan 2 diberikan lidah buaya sebanyak $100 \mathrm{mg}$ /hari dan $200 \mathrm{mg} / \mathrm{hari}$ yang diberikan dalam bentuk jus selama 14 hari. Kadar kolesterol LDL dan kadar kolesterol LDL diukur sebelum dan sesudah intervensi. Analisis kolesterol LDL dan kolestrol HDL menggunakan metode enzimatik. Data yang diperoleh dianalisis menggunakan uji paired ttest dan anova pada derajat kemaknaan $5 \%$.

Hasil : Pada pemberian jus Aloe vera 200 mg menyebabkan penurunan kadar kolesterol LDL dan meningkatkan kadar kolesterol HDL secara bermakna ( $p<0,05)$. Kadar kolesterol LDL menurun sebesar 20,36\% dan kadar kolesterol HDL meningkat sebesar 18,87\% setelah diberikan jus lidah buaya selama 14 hari. Pemberian jus Aloe vera 100 mg dapat menurunkan kadar kolesterol LDL tetapi juga mengalami penurunan kadar kelosterol HDL tetapi tidak bermakan $(P>0,05)$.
\end{abstract}

Simpulan: Pemberian jus lidah buaya 200 mg/hari dapat menurunkan kadar kolesterol LDL dan meningkatkan kolesterol HDL secara bermakna.

Kata kunci: jus lidah buaya; hiperlipidemia; $H D L ; L D L$

\section{PENDAHULUAN}

Penyakit jantung merupakan penyebab utama morbiditas dan mortalitas di negara maju maupun di negara berkembang. Menurut penelitian, pada tahun 2006 prevalensi penyakit jantung koroner (PJK) di Amerika terdapat 17,6

${ }^{*}$ Penulis Penanggungjawab 
juta jiwa setara 7,9\% total penduduk Amerika, dan sebanyak 425,4 ribu kematian akibat penyakit jantung koroner. ${ }^{1}$ Menurut data prevalensi penyakit jantung Badan Litbang Departemen Kesehatan RI, presentasi kematian disebabkan karena penyakit jantung meningkat dari 5,9\% (1975) menjadi 9,1\% (1986) dan 19,0\% (1995). ${ }^{2}$ Penelitian tahun 2000 RS Pusat Jantung Nasional Harapan Kita Jakarta Selatan menunjukkan, 80 persen penyebab mortalitas adalah penyakit jantung (7,2 juta) dan stroke sebanyak 5,2 juta, dan secara keseluruhan penyebab utama mortalitas 68,8 persen disebabkan karena PJK. ${ }^{2}$

Penyakit jantung koroner (PJK) adalah penyakit jantung yang terutama disebabkan oleh penyempitan atau terjadinya sumbatan pada arteri koronaria akibat proses aterosklerosis atau plak. ${ }^{2}$ Faktor risiko mayor yang berperan pada penyakit jantung koroner diantaranya adalah hipertensi, dislipidemia, pola hidup yang tidak sehat, asupan buah dan sayur yang rendah, merokok, kurang aktivitas fisik, dan obesitas. ${ }^{2}$

Penderita penyakit jantung koroner menunjukkan dislipidemia. Dislipidemia merupakan keadaan kadar kolesterol yang tinggi didalam darah. Kolesterol LDL dan kolesterol HDL adalah dua jenis lipoprotein yang berkaitan dengan penyakit jantung. ${ }^{3}$ Kadar kolesterol LDL paling signifikan pada lipid darah yang meningkatkan risiko penyakit jantung sedangkan kadar kolesterol HDL memiliki fungsi yang berkebalikan dengan kolesterol LDL dalam penyakit jantung koroner.

Profil lipid dipengaruhi beberapa faktor seperti asupan kolesterol tinggi, asupan serat yang rendah, kegemukan, kebiasaan olahraga, kebiasaan merokok, laki-laki, wanita menopause dan adanya penyakit penyerta (DM). Laki-laki lebih beresiko terhadap peningkatan profil lipid dibandingkan dengan wanita yang belum menopause. ${ }^{3}$ Asupan lemak yang tinggi meningkatkan kadar kolesterol LDL dengan cara menekan regulasi reseptor LDL di hati. Serat dapat menurunkan kolesterol dengan membantu meningkatkan ekskresi asam empedu melalui feses dan secara tidak langsung mengikat lemak yang berasal dari makanan. ${ }^{4}$

Peningkatan kolesterol HDL dan penurunan kolesterol LDL selain dapat dilakukan dengan mengkonsumsi obat, juga dapat dilakukan dengan perubahan pola hidup yang sehat dan diet. Diet merupakan cara yang efektif untuk menurunkan kolesterol LDL dan menaikkan kolesterol HDL. Salah satu bahan makanan yang dihubungkan dengan penurunan LDL dan peningkatan HDL adalah Aloe vera (lidah buaya). Aloe vera merupakan tanaman obat di Indonesia yang sering dimanfaatkan oleh masyarakat sebagai obat tradisional. ${ }^{5}$ Penelitian yang dilakukan oleh Subbiah Rajasekaran dkk di India menunjukkan bahwa aloe vera dapat menurunkan profi lipid dalam darah dan menurunkan kadar glukosa dalam darah secara signifikan. ${ }^{7}$ Kandungan Aloe vera yang diduga dapat menurunkan kolesterol LDL dan meningkatkan kolestrol HDL adalah serat larut air yaitu glukomanan, antioksidan, flavonoid, niacin, vitamin $\mathrm{C}$, magnesium, selenium, dan zinc. ${ }^{4}$

Berdasarkan penelitian pada tikus, jus Aloe vera dapat menurunkan kadar kolesterol LDL dan menaikkan kadar kolesterol HDL secara signifikan. ${ }^{6}$ Penelitian pada tikus yang dilakukan oleh Hermawan Istiadi, jus Aloe vera menunjukkan terjadinya penurunan kadar kolesterol LDL sebesar $11,85 \% \quad(2 \mathrm{ml} / \mathrm{hari})$ dan peningkatan kadar kolesterol HDL sebesar 32,95 \% (2 ml/hari). ${ }^{6}$ Penelitian yang sama juga dilakukan Umi Kotiah pada tahun 2007 yang juga menunjukkan terjadinya penurunan kadar kolesterol LDL sebesar $73,1 \%$ (1ml/hari) dan peningkatan kadar kolesterol HDL sebesar 21,68 \% (1 $\mathrm{ml} / \mathrm{hari})$ dengan pemberian ekstrak lidah buaya. ${ }^{5}$

Berdasarkan penelitian pada tahun 2007, diperoleh data yang menunjukkan bahwa 54,54\% wanita di Kantor Koperasi dan UKM (Usaha Kecil Menengah) Provinsi Jawa Tengah mengalami overweight dan asupan rata-rata seratnya sebesar $9,6 \%{ }^{8}$ Penelitian tentang pengaruh pemberian jus Aloe vera dengan dosis yang berbeda terhadap kadar kolesterol HDL dan LDL serum tikus putih dislipidemia pernah dilakukan. Namun, penelitian tentang konsumsi jus Aloe vera terhadap kadar kolesterol HDL dan LDL pada subyek dengan dislipidemia belum pernah dilakukan. Hal inilah yang mendorong peneliti untuk mengkaji lebih jauh mengenai pengaruh pemberian jus Aloe vera terhadap kolesterol HDL dan LDL pada subyek dengan dislipidemia dengan kadar lidah buaya yang berbeda.

\section{METODE}

Penelitian ini merupakan jenis true experiment dengan pre test - post test with control group design dengan pemberian jus lidah buaya (Aloe vera), dengan dosis 100 gram/hari dan 200 gram/hari. Penelitian dilakukan di Dinas Koperasi dan UKM Provinsi Jawa Tengah serta Balai Latihan Koperasi dan UKM Provinsi Jawa Tengah.

Populasi penelitian adalah semua wanita usia lebih dari 40 tahun hingga belum menopause. 
Besar sampel dihitung dengan menggunakan rumus besar sampel uji hipotesis terhadap rerata dua populasi pada dua kelompok independen ${ }^{9}$ dengan simpangan baku ketiga kelompok yang didapatkan dari penelitian sebelumnya, yakni $17,919^{10}$; perbedaan klinis yang diinginkan peneliti sebesar 13,4 mg/dl; tingkat kemaknaan $95 \%$ dan power $80 \%$, sehingga didapatkan sampel sebanyak 15 orang untuk tiap kelompok.

Subyek penelitian diambil secara consecutive sampling dari 90 orang populasi yang memenuhi kriteria inklusi mempunyai kadar kolesterol LDL > $130 \mathrm{mg} / \mathrm{dl}$ dan kolesterol HDL < $60 \mathrm{mg} / \mathrm{dl}$, memiliki indeks massa tubuh $\geq 23 \mathrm{~kg} / \mathrm{m}^{2}$ $-30 \mathrm{~kg} / \mathrm{m}^{2}$, dapat diajak komunikasi, tidak dalam kondisi sakit atau dalam perawatan dokter berkaitan dengan penyakit DM, PJK, dan penyakit kronis lainnya, tidak menderita penyakit familial dyslipidemia, tidak sedang mengkonsumsi obatobatan yang mengendalikan kadar kolesterol darah selama penelitian, dan tidak mengkonsumsi obat hipertensi sejenis beta bloker serta bersedia menjadi subyek penelitian dengan mengisi informed consent. Setelah didapatkan jumlah subyek 45 orang kemudian dikelompokkan menjadi tiga kelompok, yaitu kelompok kontrol, kelompok perlakuan 1 dan kelompok perlakuan 2.

Kelompok perlakuan diberikan intervensi jus lidah buaya sedangkan kelompok kontrol tidak diberi jus lidah buaya. Dosis pemberian jus lidah buaya pada subyek didasarkan pada dosis yang diberikan pada tikus pada penelitian sebelumnya. Setelah dikonversi, maka diperoleh masing masing kelompok perlakuan pertama dan kelompok perlakuan kedua adalah dosis $100 \mathrm{mg} /$ hari dan $200 \mathrm{mg} /$ hari.

Minuman jus lidah buaya diberikan selama 14 hari dan kepatuhan mengkonsumsi minuman lidah buaya dipantau dengan menggunakan checklist. Pemberian minuman jus lidah buaya dilakukan secara langsung oleh peneliti di kantor ataupun di rumah subyek. Selama penelitian, peneliti juga mencatat dan memantau efek samping pemberian minuman jus lidah buaya yang dirasakan oleh subyek. Pemberian minuman jus lidah buaya dilakukan diantara makan pagi dan makan siang. Selama pelaksanaan penelitian dilakukan upaya merekam asupan makanan masing-masing subyek dengan menggunakan metode food record dan food recall 24 jam pada hari ke-2, ke-6, dan ke-13. Pada hari ke-15 dilakukan pengukuran kembali kadar kolesterol LDL dan kadar kolesterol HDL sebagai data akhir penelitian.
Pengumpulan data dilakukan dengan wawancara dan pemeriksaan. Data umum subyek yaitu nama, umur, alamat, nomor telepon, riwayat keluarga menderita PJK/hiperkolesterolemia, atau penyakit kronis lain, keadaan subyek didapatkan melalui wawancara dengan responden yang dicatat pada kuesioner data umum subyek. Data asupan makan subyek yang juga dilakukan dengan wawancara adalah food recall $24 \mathrm{jam}$. Data berat badan sebelum dan setelah intervensi dilakukan dengan menimbang subyek menggunakan timbangan digital kapasitas $120 \mathrm{~kg}$ dengan ketelitian $0,1 \mathrm{~kg}$, sedangkan tinggi badan subyek diperoleh dengan menggunakan mikrotoise kapasitas 2 meter dengan ketelitian $0,1 \mathrm{~cm}$ yang kemudian dicatat pada kuesioner data umum subyek. Pemeriksaan kadar kolesterol LDL dan kolesterol HDL diukur oleh laboratorium " $X$ " dan dicatat pada kuesioner data umum subyek.

Variabel pengaruh pada penelitian ini adalah konsumsi jus lidah buaya yang diukur dalam satuan gram, variabel terpengaruh adalah kadar kolesterol LDL dan kolesterol HDL, variabel perancunya adalah asupan makan meliputi rata-rata asupan energi, rata-rata asupan protein, rata-rata asupan lemak, rata-rata asupan serat, dan rata-rata asupan kolesterol yang berasal dari makanan dan minuman yang dikonsumsi selama intervensi. Data asupan makan yang diperoleh dengan menggunakan food recall 24 jam dalam ukuran rumah tangga dikonversikan kedalam satuan gram kemudian dihitung nilai energi, protein, lemak, karbohidrat, serat, dan kolesterol dengan menggunakan program nutrisoft.

Seluruh data yang diperoleh terlebih dahulu dilakukan uji normalitas untuk menguji kenormalan data dengan uji Saphiro Wilks. Perbedaan kadar kolesterol LDL dan kolesterol HDL sebelum dan sesudah intervensi diuji dengan paired t-test. Perbedaan pengaruh dari ketiga kelompok perlakuan dianalisis menggunakan uji statistik parametrik Anova. Kemudian dilanjutkan dengan uji LSD (Least Significant Difference) pada tingkat kepercayaan $95 \%$.

\section{HASIL PENELITIAN \\ Karakteristik Subyek Penelitian}

Penelitian dilakukan pada bulan Januari 2012 sampai dengan bulan Mei 2012. Dari 45 orang dislipidemia yang terpilih sebagai subyek penelitian, 43 subyek menyelesaikan kegiatan penelitian yaitu 15 subyek dari kelompok komtrol, 14 subyek dari kelompok perlakuan pertama, dan 14 subyek dari kelompok perlakuan kedua. 
Terdapat dua subyek yang drop out dari penelitian yang terdiri dari 1 subyek dari kelompok perlakuan pertama dan 1 subyek dari kelompok perlakuan kedua. Subyek yang drop out adalah subyek yang berhenti mengkonsumsi jus lidah buaya karena alasan mual, perut perih dan lupa. Karakteristik subyek (umur, indeks massa tubuh, asupan lemak, asupan serat, asupan kolesterol, asupan karbohidrat, asupan protein dan asupan energi) pada ketiga kelompok dapat dilihat pada tabel 1 .

Tabel 1. Karakteristik subyek penelitian

\begin{tabular}{|c|c|c|c|c|}
\hline \multirow{3}{*}{ Variabel } & \multicolumn{3}{|c|}{ Kelompok } & \multirow[b]{2}{*}{$P^{a}$} \\
\hline & Kontrol $(n=15)$ & $\begin{array}{c}\text { Perlakuan } 1 \\
(\mathrm{n}=14)\end{array}$ & $\begin{array}{c}\text { Perlakuan } 2 \\
(n=14)\end{array}$ & \\
\hline & Rerata \pm SD & Rerata \pm SD & Rerata \pm SD & \\
\hline $\begin{array}{l}\text { Umur (thn) } \\
\text { / Min-max }\end{array}$ & $\begin{array}{c}47,53 \pm 3,66 / \\
40-52\end{array}$ & $\begin{array}{c}45,93 \pm 3,269 / \\
40-51\end{array}$ & $\begin{array}{c}46,79 \pm 3,45 / \\
40-51\end{array}$ & $0,332^{b}$ \\
\hline IMT & $26,6 \pm 2,32$ & $26,75 \pm 2,29$ & $27,72 \pm 2,46$ & 0,392 \\
\hline Asupan Lemak (gr) & $78,01 \pm 14,74$ & $76,52 \pm 13,78$ & $76,59 \pm 12,14$ & 0,968 \\
\hline Asupan serat (gr) & $10,27 \pm 1,77$ & $11,28 \pm 1,93$ & $10,81 \pm 1,44$ & 0,247 \\
\hline $\begin{array}{l}\text { Asupan } \\
\text { (mg) }\end{array}$ & $\begin{array}{c}401,47 \pm 171,26 \\
228,91 \pm 30,51\end{array}$ & $\begin{array}{c}318,78 \pm 121,96 \\
220,06 \pm 37,02\end{array}$ & $\begin{array}{l}284,92 \pm 95,97 \\
227,06 \pm 40,91\end{array}$ & $\begin{array}{l}0,093 \\
0,746\end{array}$ \\
\hline $\begin{array}{l}\text { Asupan Karbohidrat } \\
\text { (gr) }\end{array}$ & $\begin{array}{c}77,22 \pm 9,46 \\
1910,22 \pm\end{array}$ & $\begin{array}{c}79,78 \pm 10,97 \\
1871,19 \pm 190,88\end{array}$ & $\begin{aligned} 73,02 & \pm 7,95 \\
1872,51 & \pm 179,54\end{aligned}$ & $\begin{array}{l}0,180 \\
0,798\end{array}$ \\
\hline $\begin{array}{l}\text { Asupan Protein (gr) } \\
\text { Asupan Energi (kkal) }\end{array}$ & 163,26 & & & \\
\hline
\end{tabular}

Keterangan : $a=$ one way anova $; b=$ kruscal wills

Tabel 1 menunjukkan tidak ada perbedaan karakteristik subyek ( umur, indeks massa tubuh, asupan lemak, asupan serat, asupan kolesterol, asupan karbohidrat, asupan protein, dan asupan energi) antara kelompok kontrol, perlakuan pertama dan perlakuan kedua.
Kadar kolesterol LDL dan kadar kolesterol HDL subyek sebelum intervensi

Kadar kolesterol LDL dan kadar kolesterol HDL subyek sebelum intervensi pada kelompok kontrol, perlakuan pertama, dan perlakuan kedua dapat dilihat pada tabel 2.

Tabel 2. Kadar kolesterol LDL dan kadar kolesterol HDL subyek sebelum intervensi pada kelompok kontrol, perlakuan pertama, dan perlakuan kedua

\begin{tabular}{cllcc}
\hline & \multicolumn{3}{c}{ Kelompok } & \\
\cline { 2 - 4 } Profil Lipid & Kontrol (n=15) & $\begin{array}{l}\text { Perlakuan } \\
(\mathrm{n}=14)\end{array}$ & $\begin{array}{l}\text { Perlakuan } \\
(\mathrm{n}=14)\end{array}$ & $P^{a}$ \\
\cline { 2 - 4 } & \multicolumn{1}{c}{ Rerata \pm SD } & \multicolumn{1}{c}{ Rerata \pm SD } & Rerata \pm SD & \\
\hline Kol. LDL (mg/dl) & $168,36 \quad \pm$ & $161,46 \pm 20,26$ & $176,25 \pm 28,62$ & 0,245 \\
Kol HDL (mg/dl) & 19,89 & $45,78 \pm 7,03$ & $43,29 \pm 10,15$ & 0,636 \\
& $42,57 \pm 6,3$ & & & \\
\hline
\end{tabular}

Keterangan : $a=0$ ene way anova

Berdasarkan uji Shapiro Wilk diketahui bahwa semua sebaran data normal $(p>0,05)$ sehingga dilanjutkan dengan uji statistik parametrik. Tabel 2 menunjukkan tidak ada perbedaan kadar kolesterol LDL dan kadar kolesterol HDL subyek sebelum intervensi antara kelompok kontrol, perlakuan pertama dan perlakuan kedua.

\section{Asupan zat gizi subjek penelitian selama intervensi}

Asupan zat gizi subyek selama intervensi dapat dilihat pada tabel 3 dibawah ini. 
Tabel 3. Asupan zat gizi subjek penelitian selama intervensi

\begin{tabular}{|c|c|c|c|c|}
\hline \multirow{3}{*}{ Variabel } & \multicolumn{3}{|c|}{ Kelompok } & \multirow{3}{*}{$p^{a}$} \\
\hline & Kontrol $(n=15)$ & $\begin{array}{l}\text { Perlakuan } 1 \\
(\mathrm{n}=14)\end{array}$ & $\begin{array}{l}\text { Perlakuan } 2 \\
(n=14)\end{array}$ & \\
\hline & Rerata \pm SD & Rerata \pm SD & Rerata \pm SD & \\
\hline Asupan & $70,39 \pm 13,47$ & $77,08 \pm 8,05$ & $81,94 \pm 7,77$ & $0,014^{b}$ \\
\hline (gr) & $10,97 \pm 1,24$ & $9,94 \pm 0,76$ & $9,58 \pm 1,15$ & 0,004 \\
\hline Asupan serat (gr) & $330,9 \pm 151,18$ & $296,5 \pm 121,37$ & $338,36 \pm 121,85$ & 0,676 \\
\hline Kolesterol & $228,44 \pm 31,99$ & $206,63 \pm 22,08$ & $203,52 \pm 28,22$ & $0,093^{b}$ \\
\hline (mg) & $70,87 \pm 6,99$ & $80,93 \pm 11,45$ & $84,14 \pm 11,22$ & 0,003 \\
\hline $\begin{array}{ll}\text { As. } & \text { Karbohidrat } \\
\text { (gr) } & \end{array}$ & $\begin{array}{c}1813,12 \pm \\
189,48\end{array}$ & $1824,39 \pm 54,47$ & $1879,44 \pm 82,78$ & $0,127^{b}$ \\
\hline $\begin{array}{l}\text { As. Protein (gr) } \\
\text { As. Eneroi (kkal) }\end{array}$ & & & & \\
\hline As. Energ & & & & \\
\hline
\end{tabular}

Tabel 3 menunjukkan bahwa terdapat perbedaan asupan lemak, asupan serat, dan asupan protein antara ketiga kelompok $(p<0,05)$. Asupan kolesterol, asupan karbohidrat, dan asupan energi pada ketiga kelompok tidak memiliki perbedaan dengan nilai $\mathrm{p}>0,05$.

\section{Kadar kolesterol LDL dan kadar kolesterol HDL subyek sesudah intervensi}

Kadar kolesterol LDL dan kadar kolesterol HDL sesudah 14 hari pemberian jus lidah buaya 100 gram dan 200 gram sekali sehari selama 14 hari pada kelompok perlakuan pertama dan kelompok perlakuan kedua dan pemberian placebo pada kelompok kontrol dapat dilihat pada tabel 3.

Tabel 4. Kadar kolesterol LDL dan kadar kolesterol HDL subyek sesudah intervensi pada kelompok kontrol, perlakuan pertama, dan perlakuan kedua

\begin{tabular}{|c|c|c|c|c|c|}
\hline \multirow{3}{*}{ Profil Lipid } & \multicolumn{4}{|c|}{ Kelompok } & \multirow{3}{*}{$P^{a}$} \\
\hline & Kontrol $(n=15)$ & $\begin{array}{l}\text { Perlakuan } \\
(\mathrm{n}=14)\end{array}$ & 1 & $\begin{array}{l}\text { Perlakuan } \\
(\mathrm{n}=14)\end{array}$ & \\
\hline & Rerata \pm SD & Rerata \pm SD & & Rerata \pm SD & \\
\hline Kol. LDL (mg/dl) & 160,90 & $160,88 \pm 32,84$ & & $140,36 \pm 38,86$ & 0,245 \\
\hline Kol. HDL (mg/dl) & $\begin{array}{l}38,75 \\
45,67 \pm 10,89\end{array}$ & $42,07 \pm 6,95$ & & $53,36 \pm 11,74$ & 0,016 \\
\hline
\end{tabular}

Keterangan: a=one way anova

Hasil analisis uji one way anova menunjukkan tidak ada perbedaan kadar kolesterol LDL $(\mathrm{p}=0,245)$ subyek sesudah intervensi antara kelompok kontrol, kelompok perlakuan pertama dan kelompok perlakuan kedua. Sedangkan hasil analisis uji one way anova terdapat perbedaan kadar kolesterol HDL $(\mathrm{p}=0,016)$ subyek sesudah intervensi antara kelompok kontrol, kelompok perlakuan pertama dan kelompok perlakuan kedua (tabel 3). Terdapat peningkatan kadar kolesterol HDL pada kelompok dosis $200 \mathrm{mg} / \mathrm{hari}$ dibandingkan kelompok kontrol dan kelompok dosis $100 \mathrm{mg}$, tetapi tidak terdapat peningkatan kadar kolesterol HDL yang bermakna pada kelompok perlakuan dosis $100 \mathrm{mg} / \mathrm{hari}$ dibandingkan kelompok kontrol (tabel 5).

Tabel 5. Hasil analisis Post Hoc Kadar Kolesterol HDL sesudah intervensi

\begin{tabular}{|c|c|c|c|c|}
\hline \multicolumn{5}{|c|}{ HDL } \\
\hline & & Kontrol $(n=15)$ & Perlakuan $1(n=14)$ & Perlakuan $2(n=14)$ \\
\hline Kontrol $(n=15)$ & & - & 0,344 & 0,047 \\
\hline $\begin{array}{l}\text { Perlakuan } \\
(n=14)\end{array}$ & 1 & 0,344 & - & 0,05 \\
\hline
\end{tabular}


Perbandingan kadar kolesterol LDL dan kadar kolesterol HDL subyek antara sebelum dan sesudah intervensi pada kelompok kontrol

Perbandingan kadar kolesterol LDL dan kadar kolesterol HDL subyek antara sebelum dan sesudah intervensi pada kelompok kontrol, kelompok perlakuan pertama dan kelompok perlakuan kedua dapat dilihat pada tabel 6 .

Tabel 6. Perbandingan kadar kolesterol LDL dan kadar kolesterol HDL subyek antara sebelum dan sesudah intervensi pada kelompok kontrol, kelompok perlakuan pertama dan kelompok perlakuan kedua

\begin{tabular}{rlll}
\hline \multirow{2}{*}{ Profil Lipid } & \multicolumn{3}{c}{ Kontrol $(\mathrm{n}=15)$} \\
\cline { 2 - 3 } & Sebelum & Sesudah & \multirow{2}{*}{$P^{c}$} \\
\cline { 2 - 3 } & Rerata \pm SD & Rerata \pm SD & 0,490 \\
\hline Kol. LDL $(\mathrm{mg} / \mathrm{dl})$ & $168,36 \pm 19,89$ & $159,3 \pm 39,7$ & 0,40 \\
\hline Kol. HDL $(\mathrm{mg} / \mathrm{dl})$ & $42,57 \pm 6,3$ & $45,36 \pm 11,24$ & 0,454 \\
\hline
\end{tabular}

\begin{tabular}{|c|c|c|c|c|c|}
\hline Perlakuan $1(n=14$ & & & Perlakuan $2(\mathrm{n}=1$ & & \multirow{3}{*}{$P^{c}$} \\
\hline Sebelum $(n=14)$ & Sesudah $(n=14)$ & \multirow{2}{*}{$P^{c}$} & Sebelum $(n=14)$ & Sesudah $(n=14)$ & \\
\hline Rerata \pm SD & Rerata \pm SD & & Rerata \pm SD & Rerata \pm SD & \\
\hline $161,46 \pm 20,26$ & $160,88 \pm 32,84$ & 0,942 & $176,25 \pm 28,62$ & $140,36 \pm 38,86$ & 0,002 \\
\hline $45,78 \pm 7,03$ & $42,07 \pm 6,9$ & 0,060 & $43,29 \pm 10,15$ & $53,36 \pm 11,74$ & 0,003 \\
\hline
\end{tabular}

Keterangan: $c=$ paired $T$-test

Hasil uji paired T-test pada kelompok kontrol menunjukkan bahwa tidak ada perbedaan kadar kolesterol LDL $(\mathrm{p}=0,490)$ dan kadar kolesterol HDL $(p=0,454)$ subyek antara sebelum dan sesudah intervensi. Tabel 6 juga menunjukkan bahwa tidak ada perbedaan kadar kolesterol LDL $(\mathrm{p}=0,942)$ dan kolesterol HDL $(\mathrm{p}=0,060)$ subyek antara sebelum dan sesudah intervensi pada kelompok perlakuan pertama. Pada kelompok perlakuan kedua menunjukkan ada perbedaan kadar kolesterol LDL $(\mathrm{p}=0,002)$ dan kolesterol HDL $(p=0,003)$ subyek antara sebelum dan sesudah intervensi.
Perubahan kadar kolesterol LDL dan kadar kolesterol HDL antara sebelum dan sesudah intervensi pada kelompok kontrol, kelompok perlakuan pertama, dan kelompok perlakuan kedua

Perubahan kadar kolesterol LDL dan kadar kolesterol HDL antara sebelum dan sesudah intervensi pada kelompok kontrol, kelompok perlakuan pertama, dan kelompok perlakuan kedua dapat dilihat pada tabel 8 .

Tabel 8. Perubahan kadar kolesterol LDL dan kadar kolesterol HDL antara sebelum dan sesudah intervensi pada kelompok kontrol, kelompok perlakuan pertama, dan kelompok perlakuan kedua

\begin{tabular}{ccccc}
\hline \multirow{3}{*}{ Profil lipid } & \multicolumn{3}{c}{ Kelompok } & \multirow{2}{*}{$P^{a}$} \\
\cline { 2 - 4 } & Kontrol (n=15) & Perlakuan 1 (n=14) & Perlakuan 2 (n=14) & \\
\cline { 2 - 4 } & Rerata \pm SD & Rerata \pm SD & Rerata \pm SD & \\
\hline Kol. LDL (mg/dl) & $9,05 \pm 37,21$ & $0,57 \pm 28,91$ & $35,89 \pm 35,48$ & 0,02 \\
\hline Kol. HDL (mg/dl) & $2,78 \pm 12,43$ & $-2,86 \pm 7,19$ & $10,07 \pm 10,24$ & 0,006 \\
\hline
\end{tabular}

Keterangan : $a=$ one way anova

Tabel 8 menunjukkan ada perbedaan perubahan kadar kolesterol LDL $(\mathrm{p}=0,02)$ dan perubahan kadar kolesterol HDL $(\mathrm{p}=0,006)$ subyek antara sebelum dan sesudah intervensi pada kelompok kontrol, kelompok perlakuan pertama dan kelompok perlakuan kedua.

\section{PEMBAHASAN}

Pada penelitian ini tidak ada perbedaan signifikan umur, indeks massa tubuh, jenis kelamin, asupan lemak, asupan serat, asupan kolesterol, asupan karbohidrat, asupan protein, asupan energi, kadar kolesterol LDL dan kadar kolesterol HDL antara ketiga kelompok sebelum penelitian, sehingga perubahan kadar kolesterol 
LDL dan kadar kolesterol HDL sesudah intervensi disebabkan oleh efek intervensi jus lidah buaya.

Pemberian jus lidah buaya pada kelompok perlakuan pertama dengan dosis $100 \mathrm{mg} / \mathrm{hari}$ selama 14 hari mengalami penurunan kadar kolesterol sebanyak $0,57 \mathrm{mg} / \mathrm{dl}$ tetapi penurunan ini tidak bermakna $(p>0,05)$. Pada kelompok perlakuan kedua dengan dosis $200 \mathrm{mg} /$ hari selama 14 hari terdapat penurunan kadar kolesterol LDL sebanyak $35,89 \mathrm{mg} / \mathrm{dl}$ atau $20,36 \%$ secara bermakna $(p<0,05)$. Penurunan ini sejalan dengan penelitian pada tikus yang diberikan jus lidah buaya $3 \mathrm{ml} /$ hari menunjukkan penurunan kadar kolesterol LDL dalam serum darah. ${ }^{6}$ Penelitian yang memberikan ekstrak lidah buaya dengan kadar $0,5 \mathrm{ml}, 1 \mathrm{ml}$, dan $1,5 \mathrm{ml} / 200 \mathrm{grBB} /$ hari pada tikus mampu mendapatkan kadar kolesterol LDL lebih rendah pada semua kelompok lidah buaya dibandingkan kelompok kontrol. ${ }^{5}$ Penurunan ini diduga karena salah satu kandungan lidah buaya yaitu glukomanan, zat yang merupakan serat larut. $^{5,11,12}$ Glukomanan dipercaya dapat menurunkan kadar risiko penyakit kardiovaskuler dengan menurunkan kadar lipid didalam plasma melalui mekanisme peningkatan viskositas kandungan intestinal sehingga dapat menurunkan reabsorbsi asam empedu dan memperlambat absorbsi serat, sehingga meningkatkan ekskresi asam empedu dan menurunkan asupan energi secara keseluruhan. ${ }^{13}$ Sebuah meta-analysis juga menyimpulkan bahwa pemberian kapsul glukomanan dapat menurunkan kadar kolesterol LDL secara bermakna. ${ }^{12}$ Penelitian pada pasien obesitas mengenai pengaruh glukomanan terhadap kadar kolesterol LDL yang dilakukan selama 4 minggu juga memiliki penurunan kadar kolesterol yang bermakna. ${ }^{11}$

Lidah buaya dapat menurunkan kadar kolesterol LDL secara bermakna karena mengandung berbagai bahan aktif seperti; niasin (vitamin B3), yang dapat menurunkan produksi kolesterol VLDL, sehingga kadar kolesterol IDL dan kadar kolesterol LDL juga turun; vitamin C, yang mempunyai efek membantu hidroksilasi dalam pembentukan asam empedu sehingga meningkatkan ekskresi kolesterol. ${ }^{414}$ Magnesium, meningkatkan sekresi kolesterol dengan meningkatkan aktivitas enzim HMG Ko-A reduktase dan menurunkan kadar kolesterol. ${ }^{15}$ Vitamin E dan vitamin A, bertindak sebagai antioksidan yang dapat melindungi kolesterol LDL dari oksidasi. ${ }^{16}$ Penurunan kadar kolesterol LDL pada kelompok pertama dengan dosis $100 \mathrm{mg} / \mathrm{dl}$ tidak bermakna disebabkan karena dosis lidah buaya yang terlalu rendah, sehingga tidak mempengaruhi penurunan kadar kolesterol LDL.

Pemberian jus lidah buaya juga berpengaruh terhadap kadar kolesterol HDL. Peningkatan kadar kolesterol HDL secara bermakna $(p<0,05)$ terjadi pada kelompok kedua dengan dosis $200 \mathrm{mg} / \mathrm{dl}$ selama 14 hari. Peningkatan kadar kolesterol HDL setelah intervensi meningkat sebanyak $10,07 \mathrm{mg} / \mathrm{dl}$. Peningkatan kadar kolesterol ini sesuai dengan penelitian yang dilakukan oleh Hermawan yang memberikan jus lidah buaya dengan dosis 3 $\mathrm{ml} / 200 \mathrm{grBB} /$ hari selama 4 minggu pada tikus yang diberikan diet tinggi kolesterol dapat meningkatkan kadar kolesterol HDL secara bermakna. ${ }^{6}$ Lidah buaya juga dapat meningkatkan kadar kolesterol HDL karena lidah buaya mengandung bahan aktif seperti; niasin, yang dapat meningkatkan produksi Apoliporotein A-1 sehingga kadar HDL meningkat. ${ }^{\mathrm{j}}$ Magnesium, yang dapat meningkatkan produksi Apolipoprotein A-IV dan Apolipoprotein E sehingga HDL kolesterol meningkat. ${ }^{15}$ Selenium dan zinc yang terbukti dapat meningkatkan kadar kolesterol HDL dan menurunkan peroksidasi lipid plasma. ${ }^{16}$ Vitamin C pada lidah buaya juga mampu meningkatkan kadar kolesterol HDL. Mekanisme vitamin C dalam meningkatkan kadar kolesterol HDL yakni dengan cara meningkatkan mRNA apolipoprotein A-1 hati yang berperan dalam sintesis apolipoprotein A-1 dan meningkatkan kadar apolipoprotein A-1 didalam darah. Apoliporotein A-1 merupakan komponen utama kolesterol HDL. ${ }^{17}$

Perubahan kadar kolesterol HDL pada pemberian jus lidah buaya $100 \mathrm{gr} / \mathrm{hari}$ justru mengalami penurunan tetapi penurunannya tidak bermakna $(p>0,05)$. Asupan lemak pada kelompok perlakuan jus lidah buaya $200 \mathrm{mg}$ lebih tinggi dibandingkan asupan lemak pada kelompok perlakuan jus lidah buaya $100 \mathrm{mg}$, akan tetapi asupan serat pada kelompok perlakuan dengan jus lidah buaya $100 \mathrm{mg}$ lebih tinggi dibandingkan kelompok perlakuan dengan jus lidah buaya 200 mg. Faktor yang lain yang dapat meningkatkan kadar kolesterol HDL adalah aktifitas fisik. Aktifitas fisik mampu meningkatkan kolesterol HDL-C dan menurunkan kolesterol LDL-C, menurunkan tekanan darah, menurunkan obesitas, dan menurunnya resistensi insulin. ${ }^{17}$ Pada penelitian ini tidak meneliti mengenai aktifitas fisik subyek, sehingga tidak diketahui efeknya terhadap kadar kolesterol HDL.

\section{SIMPULAN}


Penelitan ini membuktikan bahwa konsumsi jus lidah buaya $200 \mathrm{mg} /$ hari selama 14 hari mampu menurunkan kadar kolesterol LDL sebesar 20,36\% dan meningkatkan kolesterol HDL sebesar $18,87 \%$.

\section{SARAN DAN REKOMENDASI}

Penelitan ini membuktikan bahwa konsumsi $200 \mathrm{mg}$ jus lidah buaya perhari selama 14 hari dapat meningkatkan kolesterol HDL dan menurunkan kolesterol LDL. Akan tetapi, perlu kiranya dilakukan penelitian lebih lanjut mengenai pengaruh jus lidah buaya dengan dosis yang lebih tinggi dan pengaruh jus lidah buaya dalam jangka waktu yang lebih lama.

\section{DAFTAR PUSTAKA}

1. American Heart Association. Heart Disease and Stroke Statistics. 2010. [serial online][dikutip 22 Agustus 2011] Available from: http://www.AHA.com/pdf.

2. Zain. Kesehatan Jantung. 2009.

3. Krummel D. Medical nutrition therapy in cardiovascular diseases. In: Mahan LK, Escott SS. Krause, Food, Nutrition and Diet Therapy. $11^{\text {th }}$ ed. Pensylvania: Saunders; 2004. hal: 881-896.

4. Mayes P.A. Pengangkutan dan penyimpanan lipid. Dalam : Murray RK, Granner DK, Mayes PA, Rodwell VW. Biokimia Harper. $25^{\text {th }}$ ed. Jakarta: Penerbit Buku Kedokteran EGC; 2003.hal.257262.

5. Umi K. Pengaruh Pemberian Ekstrak Lidah Buaya terhadap Kadar Kolesterol HDL dan LDL Serum Tikus Putih Hiperkolesterolemi. Skripsi Prodi Biologi, FMIPA Unnes: Semarang; 2007. hal 3236.

6. Hermawan I, Endang SS. Pengaruh Jus Lidah Buaya (Aloe Vera linn) terhadap Kadar Kolesterol Tikus Hiperlipidemia. Skripsi Fakultas Kedokteran, Undip: Semarang; 2010. [serial online][dikutip 18 Maret 2011] Available from: URL:// http://eprints.undip. ac.id/20391/1/Hermawan.pdf

7. Rajasekaran S, Ravi K, Sivagnaman K, Subramania S. Beneficial Effects of Aloe Vera Leaf Gel Extract on Lipid Profile Status in Rats with Streptozotocin Diabetis. Clinical and Experimental Pharmacology and Physiology, Tamil nadu, India. 2006. 33,232-237.

8. Natalia DP, Muflihah I. Pengaruh Konsumsi Minuman Bekatul dengan Kadar Serat yang Berbeda terhadap Kadar Kolesterol Darah. Skripsi Prodi Ilmu Gizi, FK Undip: Semarang; 2007. Hal 13-14.

9. Bambang Madiyono, Budiman I. Perkiraan besar sampel. Dalam: Sastroasmoro S, Ismail S, editor.
Dasar-dasar metodologi penelitian klinis. $2^{\text {nd }}$ ed. Jakarta: Sagung seto; 2002. Hal. 259-66.

10. Wiwid Widiyatni, Muflihah Isnawati. Pengaruh konsumsi puding rumput laut Euchema Cottoni dengan kadar serat berbeda terhadap kadar gula darah dan kolesterol darah. Skripsi Prodi Ilmu gizi,FK Undip: Semarang; 2004.hal.8-10.

11. David EW, Vazgen Y, and Ali B. Effect of Glucomannan on Obese Patients: A Clinical Study. International Journal of Obesity. Moorhead State University, Moorhead, Minnesota. USA: July 1983. [serial online][dikutip 12 September 2011] Available from: http://adipozin.com/studies/ glucomannan.pdf.

12. Nitesh S, William LB, dan Craig I Coleman. Effect of Glucomannan on Plasma Lipid and Glucose Consentrations, Body Weight, and Blood Pressure: Systematic Review and Meta-analysis. The American Journal of Clinical Nutrition. America: 2008. [serial online][dikutip 14 Agustus 2011] Available

from:http://www.clinicalstudiespublishing.com/pd f/supplemental/Glucomannanfiberreviewof14studi esamericanJofClinicalnutrition.pdf .

13. Delmi Sulastri, Sri Rahayuningsih, Purwantyastuti. Pola asupan lemak, serat, dan antioksidan, serta hubungannya dengan profil lipid pada laki-laki etnik Minangkabau. Majalah Kedokteran Indonesia, 2005. Volume : 55, Nomor: 2.

14. Atherton P. Aloe vera myth and medicine. 2002. [serial online][dikutip 15 Agustus 2011] Available from:http://www.positivehealth.com/permit/article s /aloe20\%vera/aloevera.htm.

15. Rayssiuger Y, Gueux E, Durlach V, Durlach J, Nassir F, Mazur A. Magnesium and the cardiovascular system: New Experimental data on magazine and lipoproteins. 1997. [serial online][dikutip 12 Agustus 2011] Available from: http://www.mgwater .com/dur24.htm.

16. Anonymous. Advanced multi_vitamin. 2003. [serial online][dikutip 15 Agustus 2011] Available from: $\quad$ http://www.beverage.com/AAIC3 /information\%20multivitamin.htm

17. Brown CT. Penyakit aterosklerotik koroner. Dalam: Price SA, Wilson LM. Patofisiologi konsep klinis proses-proses penyakit. $6^{\text {th }}$ ed. Jakarta: Penerbit Buku Kedokteran EGC; 2003. 576-611. 